\title{
UNIVERSITY STUDENTS' NEEDS OF WRITING COURSE MATERIALS: A CASE OF INDONESIA
}

\author{
Ilham \\ English Education Department, Faculty of Teacher Training and Education, \\ Universitas Pendidikan Indonesia, Indonesia \\ Email: ilham.ummataram@gmail.com \\ Bachrudin Musthafa \\ English Education Department, Faculty of Language Literature Education, \\ Universitas Pendidikan Indonesia, Indonesia \\ Email: dinmusthafa@upi.edu \\ Fazri Nur Yusuf \\ English Education Department, Faculty of Language Literature Education, \\ Universitas Pendidikan Indonesia, Indonesia \\ Email: fazrinuryusuf@upi.edu
}

\begin{abstract}
APA Citation: Ilham, Musthafa, B., \& Yusuf, F. N. (2020). University students' needs of writing course materials: A case of Indonesia. English Review: Journal of English Education, 8(2), 195202. doi: $10.25134 /$ erjee.v8i2.2988.
\end{abstract}

Received: 22-02-2020

Accepted: 15-03-2020

Published: 01-06-2020

\begin{abstract}
The aim of this study is to explore the target needs (i.e. necessities, lacks and wants) of the students to inform academic writing courses materials. A case study design was employed as this design to provide in-depth data information. To collect the data, questionnaire and interviews were used. Twenty-three undergraduate students of English department at a private university in Mataram West Nusa Tenggara who take academic writing course in the 2019-2020 academic year participated in the study. The result of the study showed that the students need to learn the types of writing texts, vocabulary and construct sentences into paragraph, have good skills in writing different genres since they are lack of grammar knowledge and vocabularies, and improvement on the aspect of teaching writing. This finding may promise implications for updating the current curriculum and materials as practiced for tertiary level English department students in an attempt to keep up with the latest changes in the methodologies of English language teaching. This study recommends that lecturers and universities should conduct a need analysis regularly and updated the curriculum with such insightful needs.
\end{abstract}

Keywords: target needs; learning needs; writing courses; materials.

\section{INTRODUCTION}

Learning materials have been scientifically confirmed as "one of the essential components of the language curriculum" in the area of language teaching and learning (Mishan \& Timmis, 2015; Richard, 2001; Tomlinson, 2012). Materials are anything which is used by teachers and leaners to facilitate the learning of a language, including coursebook, videos, graded readers, flash cards, games, websites and mobile phone interactions (Tomlinson, 2016). Instructional materials typically serve as the basis for much of the language input leaners and the language instruction that is conducted in the classroom. It was also generally agreed that most language teachers use coursebooks and that no coursebook would fulfill the needs and expectations of any class (Tomlinson, 2016). Material development play such a central role in EFL learning because they effectively mediate between the course content, the teacher and pupils. Material development can also be useful as a way helping teachers to understand and apply theories of language learning and fostering teachers' continuing personal and professional development (Bouckaert, 2018; Tomlinson, 2016).

Teaching materials are fundamental part to language learning and teaching (AugustoNavarro, 2015). It facilitates students' learning about culture, combining the linguistic competence along with the socio-cultural and communicative competence (Cruz Rondón \& Velasco Vera, 2016). Good teaching material is informative (informing the leaner about the target language), instructional (guiding the leaner in learning the language), experiential (providing the leaner with experience of the language in use, eliciting (enabling the leaner to use language) and 
exploratory (helping the learner to explore the language) (Tomlinson, 2012). Good materials may have an important role to play as they become the ' de facto ' curriculum. Materials can support novice teachers who lack confidence. Materials are deemed to provide a clear set of activities and guideline for both teacher and students (Garton \& Graves, 2014). It is also argued that appropriate coursebook can facilitate curricular change because they provide a feasible framework that both teachers and students can follow and they help teachers to fully understand and routinize change.

Language learning materials, particularly for English language learning, have gone from being a neglected area of research and publishing to one that has attracted a number of new publications (Macalister, 2016; Mishan \& Timmis, 2015; Tomlinson, 2016). The majority of previous publications focus on the use of ELT materials, namely books and chapters on design and development of materials (Tomlinson \& Masuhara, 2018) material evaluation, adaptation and exploitation (Bouzid, 2017; Işik, 2018; Kashoob, 2018; Mishan \& Timmis, 2015; Roohani \& Sharifi, 2015; Spirovska Tevdovska, 2015; Tomlinson, 2013; Tomlinson \& Masuhara, 2018; Widodo, 2015), the writing material process (Augusto-Navarro, 2015; Mishan \& Timmis, 2015; Tomlinson \& Masuhara, 2018), and types of material (Tomlinson, 2013), and adopting an ecological approach in the classroom that describes three key areas in which material interacts: education, classroom discourse and language acquisition (Garton \& Graves, 2014).

In recent review, the literature on material development focuses less on ways of selecting materials and more on application on theory to practice and practice to theory. The materials will increasingly be delivered electronically through computers and smartphones which develop locally (Soleimani \& Esmaili, 2016; Tomlinson \& Masuhara, 2018).

At this level, there is a gap to be able to contribute to the teaching material development through analysis of university students' writing needs of writing course material. It is manifestation of an effort of teachers to construct appropriate material that harmonizes with students' need and wants.

Innovative English language teaching material (textbook) will play a pivotal role. Textbook can help teachers through potentially disturbing and disruptive processes of transition, illustrate new and/or untried methodologies, gradually introduce change, and create scaffoldings on which teachers can develop their own more innovative methodology. Textbooks provides the main basis for the curriculum (Richards, 2014). Textbook determines the goals and content of teaching, as well as the method teacher use. The textbook provides a map that lays out the general content of lesson and a sense of structure that give coherence to individual lesson that give coherence to individual lessons as well as entire course. Furthermore, (Mishan \& Timmis, 2015) notes that material development has purposes as: (1) Material meet a psychological need; (2) materials provide exposure to the language; (3) materials are vehicles of information; (4) materials provide a stimulus for other activities; (5) materials can act as teacher education. Material support the teacher, complement the teacher and support the leaner (Mcgrath, 2013).

One of the most important things in developing teaching materials is the analysis of the students' need toward their learning materials. Need analysis is the starting point of course design which aims to determine learners' need in a particular learning context. Need analysis guides the teachers select appropriate taks and content and teachers' statement of goals and to provide a better understanding of the purposes of instruction for the leaner (Darici, 2016). Need analysis of learning material context is a process to find students' expectations and needs by identifying the effective way of instructional material context to be presented (Yundayani et al., 2017). Need analysis will provide insight for policy makers and stakeholders to evaluate the success of a course, find the points of strength and weaknesses as well as to do the required amendments to improve the course (Zohoorian, 2015). Identification and analysis of leaners' needs, interest, and purpose of learning will facilitate setting learning objectives, and goals, setting up positive language learning environment, enhancing leaners motivation, and the progress of specific skills such as reading and writing (Rostami \& Zafarghandi, 2014). Furthermore, identifying and analyzing learning needs will facilitate the setting of learning goals and objectives, establish a positive language learning environment, improve learning motivation and evaluate the progress of students. In addition, needs analysis helps to give teachers a clear view of students' needs, wants, and lacks and control over their learning when needs analysis is used as an ongoing teaching process. 
Needs analysis allows teacher to be aware of students' needs, their desire and shortcomings in the learning process (Al-hamlan \& Baniabdelrahman, 2015).

Pertaining to the issue of needs analysis in writing skills, the number of studies conducted in the topic of need analysis is increasing simultaneously such as the analysis of student needs for writing skills materials development (Tjalla, Akil, Hamra \& Haryanto, 2017), designing academic writing material (Ampa \& Quraisy, 2018; Ghufron, Saleh, Warsono, \& Sofwan, 2016; Ibrahim, Ali, Rahman, \& Salih, 2013; Shree, Mohd, Nor, \& Din, 2014; Sumarsono, Bagis, \& Arrafii, 2017; Yundayani, 2017, 2018), a model of instructional material of academic writing (Ghufron et al., 2016; Linh \& Suppasetseree, 2016). The current study is a need analysis which is conducted in academic writing to develop academic writing material that matches with the current curriculum and condition of learning writing for the Indonesian university context.

Based on the researcher's observation of English writing materials taught at English Department Muhammadiayah University of Mataram, it was found that the process of implementing writing skill instructional materials in the context of English classes is far from ideal, especially in terms of making students involved in the teaching and learning process. Such phenomena are due to the expectations of the students, and needs are seldom identified to meet their exact want to learn English. Teachers have limited time span in planning concrete writing materials and a lesson plan that suits students ' needs. Furthermore, teachers have not found sufficient writing materials for the leaners, either because materials are not available or because they do not reflect changes in the curriculum. The students ' writing skills are alarmingly weak and under-standard. Most of the problems are due to incompetence in grammar, coherence, ideas development selection of content thematic sentences, rhetorical conventions, mechanics organization, lack of vocabulary and improper use of vocabulary (Fareed, Ashraf \& Bilal, 2016). Moreover, the students face difficulties in academic writing since there are limited source of material which are appropriate to be implemented. In the implementation, the lecturer merely uses the textbook which is available in the market. The book itself does not represent the students' need and the curriculum (Ghufron et al., 2016). This problem can be overcome by the proper use of instructional material as one of the learning sources.

By considering the factors above, this paper aims to ascertain students' needs in learning writing skills in an English department in tertiary education. Data of students' needs revealed through needs analysis will be the basis for designing model academic writing materials. However, this study only focuses on analyzing the students' needs toward the writing materials for an academic writing course.

\section{METHOD}

This study adopts a qualitative approach as it involved the collection and qualitative data analysis. This study belongs to a case study because it focused on a particular phenomenon, situation or event within its real-life context (Merriam, 2012); (Fraenkel et al., 2012); (Silverman, 2005) and concern on "a small scale and a single case" (Bogdan \& Biklen, 1998). A single case of this study referred to the issue of need analysis for developing writing subject material. The participants in this research are 23 students in the English Department of Muhammadiyah University of Mataram. Those 23 students were chosen by purposive sampling. This study uses a close-ended checklist questionnaire and interviews with students for collecting data.

The questionnaire was used to investigate the students' target needs (i.e., what the students' needs to do in target situation). The student's target needs consist of necessities, lacks and wants. The purpose of delivering questionnaire was to find out what the students need to do to learn. The questionnaire consisted of 6 closeended checklist target needs questionnaire which described students' necessities, lacks and wants of what students need to do in order to learn. The major advantage of close-ended questions was that their coding and tabulation was straight forward and leaves no room for rater subjectivity (Dörnyei, 2003). The questionnaire was translated into Indonesian language in order to ensure that the subjects clearly understand each item. The writing class teacher helped the students to respond to the questionnaire.

The data from the questionnaire was analyzed by using descriptive statistics while the data from interview was transcribed and subsequently categorized and interpreted in a condensed body of information (Alwasilah, 2002). In addition, interviews were arrange to serve as supplementary source and help correlate the data collected from the questionnaire (Yin, 1994). For 
this reason, out of the 23 students who completed the questionnaire, 9 were selected to be interviewed to support the finding with the data collected through the questionnaires. The questions of the interview were designed on the basis of target need which involves necessities, lacks and wants.

The data analysis was guided by the research questions. It started with the data organized in the table and presented in form of explanation then moved to analysis and the last verifying the conclusion. The checklist questionnaire was analyzed using the Likert Scale as proposed by (Dörnyei, 2003). All answers item on the closeended checklist questionnaire were classified and analyzed into a percentage. The calculation of the result was changed into the percentage.

\section{RESULTS AND DISCUSSION}

The results are elaborated based on the result of questionnaires and interviews. The data elaborates students' perspectives of target needs such as necessities, lacks and wants and learning needs i.e. goal, inputs, procedures, teacher role, student role, and setting in writing subject classroom.

\section{Students' target needs in writing class}

This section discussed the students' target needs in writing class. The analysis of the response of target needs is divided into three main parts: necessities, lacks and wants. The students' views of those needs are displayed in the following table.

\section{Necessities}

Necessities is what the leaner has to know to function effectively in the target situation (Hutchinson \& Waters, 1987). The results of the students' needs in numerical are shown in table 1 below.

Table 1. Percentage and frequencies for necessities in writing skill

\begin{tabular}{|c|c|c|c|c|c|c|}
\hline \multicolumn{2}{|r|}{ Statement } & \multicolumn{4}{|c|}{ Frequencies } & \multirow[b]{2}{*}{ Sum } \\
\hline 1. & $\begin{array}{l}\text { In your opinion, are the following } \\
\text { text types needed in a Writing } \\
\text { course? }\end{array}$ & $\begin{array}{c}\text { Strongly } \\
\text { needed }\end{array}$ & Needed & $\begin{array}{l}\text { Not } \\
\text { Needed }\end{array}$ & $\begin{array}{c}\text { Strongly } \\
\text { Not Needed }\end{array}$ & \\
\hline a. & Descriptive text & $12(52 \%)$ & $11(48 \%)$ & - & - & $23(100 \%)$ \\
\hline b. & Procedure text & $6(12 \%)$ & $14(61 \%)$ & $3(13 \%)$ & - & $23(100 \%)$ \\
\hline c. & Report text & $11(48 \%)$ & $10(43 \%)$ & $2(9 \%)$ & - & $23(100 \%)$ \\
\hline $\mathrm{d}$. & Exposition text & $9(39 \%)$ & $13(57 \%)$ & $1(4 \%)$ & - & $23(100 \%)$ \\
\hline & Explanation text & $9(39 \%)$ & $13(57 \%)$ & $1(4 \%)$ & - & $23(100 \%)$ \\
\hline f. & Discussion text & $7(30 \%)$ & $15(65 \%)$ & $1(4 \%)$ & - & $23(100 \%)$ \\
\hline 2. & \multicolumn{6}{|c|}{ In your opinion, how important to master writing skill for completing writing tasks? } \\
\hline & Mastering Punctuation in English & $11(48 \%)$ & $11(48 \%)$ & $1(4 \%)$ & - & $23(100 \%)$ \\
\hline & Mastering Spelling in English & $10(43 \%)$ & $13(57 \%)$ & - & - & $23(100 \%)$ \\
\hline & $\begin{array}{l}\text { Mastering the vocabulary of } \\
\text { English }\end{array}$ & $19(83 \%)$ & $4(17 \%)$ & - & - & $23(100 \%)$ \\
\hline d. & $\begin{array}{l}\text { Arrange phrases into simple } \\
\text { sentence }\end{array}$ & $12(52 \%)$ & $11(48 \%)$ & - & - & $23(100 \%)$ \\
\hline & $\begin{array}{l}\text { Construct sentences into a } \\
\text { paragraph in English }\end{array}$ & $16(70 \%)$ & $6(26 \%)$ & $1(4 \%)$ & - & $23(100 \%)$ \\
\hline & $\begin{array}{l}\text { Understanding cohesion and } \\
\text { coherence in English. }\end{array}$ & $14(61 \%)$ & $9(39 \%)$ & - & - & $23(100 \%)$ \\
\hline
\end{tabular}

As is shown in table 1, from among the text types, discussion text, procedure text, exposition text and explanation text were highly preferred of majority students to learn in their writing class. However, another text type such as descriptive text was chosen by the students as not needed. Furthermore, about the need for mastering writing skill to complete the task of writing course, learning the vocabulary of English, constructing sentences into a paragraph, understanding cohesion, and coherence, and arrange phrases into simple sentence were highly preferred by the students. This finding implies that students are in favor of being taught those skills of writing so that they need to learn from the exercises and many sourcebooks.

The data from the questionnaire was strengthened with the interview result to provide supplementary source of information and to help corroborate the data obtained from questionnaire Yin (1994). Consistent with the result achieved through questionnaire, interviews revealed that students' need to learn different kinds of genre. The following sentences are the students' 
ENGLISH REVIEW: Journal of English Education Volume 8, Issue 2, June 2020

responses which suggest the need to learn different kinds of genre. These, for example, are stated by $\mathrm{S} 1$ and $\mathrm{S} 2$ :

"I think it's important to know the type of text because if I don't learn this type of text, I can't write arguments about an issue" (S1).

"I think it's important to learn the type of text because each text has different objectives" (S2)

The data seemed to emphasize that students need to learn different types of text because they can describe people if they have knowledge of descriptive text and each text types has different purposes.

Asked about the importance of mastering skills of writing to complete the writing task, students acknowledge that they need to have knowledge of writing skill to complete the task such as the response delivered by S3 and S4:

"I think it is important to learn how to arrange sentences into paragraphs and then to learn how to organize them in paragraph because the sentences have to be interrelated" (S3).

"It is important to master the arrangement of sentences and phrases in paragraphs, as well as
p-ISSN 2301-7554, e-ISSN 2541-3643

https://journal.uniku.ac.id/index.php/ERJEE

cohesion and coherence in order to write correctly" (S4).

The data may suggest that students seemed to aware the importance of learning the way to arrange good sentences in paragraph with good coherence and cohesion ideas. Hence, it can be inferred that the students really need the writing activity which improves their writing skill.

In brief, the response of the students leads to the conclusion that majority of the students in this study need to learn a number of text types in English, writing text type to complete writing assignments, the importance of mastering writing skill for completing writing tasks and the need of mastering writing technique to complete the writing tasks. This was in line with Nation \& Macalister (2010) who proposes that necessities such as learning text types ad mastering writing skills are the type of needs determined by the demands of the target situation, that is what the leaner has to know to function effectively in the target situation.

Lacks

Lacks refers to the gaps between the existing proficiency of the leaner and the target proficiency. The result of the students' response on lacks is illustrate in detail in the following table.

Table 2. Percentage and frequencies for lack in writing skill

\begin{tabular}{|c|c|c|c|c|c|c|}
\hline \multicolumn{2}{|r|}{ Statement } & \multicolumn{5}{|c|}{ Frequencies } \\
\hline 1. & $\begin{array}{l}\text { In your opinion, how well you can } \\
\text { write text type in writing class? }\end{array}$ & $\begin{array}{l}\text { Very } \\
\text { good }\end{array}$ & Good & Fair & Poor & Sum \\
\hline & a. Writing Descriptive text & - & $14(61 \%)$ & $8(35 \%)$ & $1(4 \%)$ & $23(100 \%)$ \\
\hline & b. Writing Narrative text & - & $11(48 \%)$ & $10(43 \%)$ & $2(9 \%)$ & $23(100 \%)$ \\
\hline & c. Writing Exposition text & - & $7(30 \%)$ & $14(61 \%)$ & $2(9 \%)$ & $23(100 \%)$ \\
\hline & d. Writing Explanation text & - & $9(39 \%)$ & $13(57 \%)$ & $1(4 \%)$ & $23(100 \%)$ \\
\hline & e. Writing Discussion text & - & $13(57 \%)$ & $9(39 \%)$ & $1(4 \%)$ & $23(100 \%)$ \\
\hline \multicolumn{7}{|c|}{ 2. In your opinion, what difficulties do you have in writing class? } \\
\hline \multicolumn{2}{|r|}{ Option } & \multicolumn{2}{|c|}{ Yes } & \multicolumn{2}{|c|}{ No } & Sum \\
\hline & $\begin{array}{ll}\text { a. } & \text { Difficulties determining topic }\end{array}$ & \multicolumn{2}{|c|}{$10(43 \%)$} & \multicolumn{2}{|c|}{$13(57 \%)$} & $23(100 \%)$ \\
\hline & $\begin{array}{l}\text { b. difficulty of putting ideas into } \\
\text { writing }\end{array}$ & \multicolumn{2}{|c|}{$17(74 \%)$} & \multicolumn{2}{|c|}{$6(26 \%)$} & $23(100 \%)$ \\
\hline & $\begin{array}{l}\text { c. Difficulty of developing ideas } \\
\text { into paragraphs }\end{array}$ & \multicolumn{2}{|c|}{$17(74 \%)$} & \multicolumn{2}{|c|}{$6(26 \%)$} & $23(100 \%)$ \\
\hline & d. Limited English vocabulary & \multicolumn{2}{|c|}{$18(78 \%)$} & \multicolumn{2}{|c|}{$5(22 \%)$} & $23(100 \%)$ \\
\hline & e. Lack of spelling knowledge & \multirow{2}{*}{\multicolumn{2}{|c|}{$\begin{array}{l}14(61 \%) \\
20(87 \%)\end{array}$}} & \multirow{2}{*}{\multicolumn{2}{|c|}{$\begin{array}{l}9(39 \%) \\
3(13 \%)\end{array}$}} & $23(100 \%)$ \\
\hline & f. Lack of grammar knowledge & & & & & $23(100 \%)$ \\
\hline
\end{tabular}

Table 2 shows that the ability of students on writing exposition text, and explanation text were on a fair level; meanwhile, writing descriptive text and writing discussion text were on a good level. Regarding the data of students difficulties in writing class, the data shows that grammar was the greatest area of difficulties, though limited vocabulary, difficulties of putting ideas into writing and difficulties of putting ideas into paragraph also proposed serious problem. The next serious problem was spelling while determining a topic was a less serious problem.

It was also stated by some students from the interview result that most of their ability of 
writing text type were in adequate level. In addition, they had difficulties in learning writing such as they had difficulties of determining a topic, develops ideas into paragraphs, and difficulties of vocabulary skill because of lack of practice and reading. Other students' difficulties were not too good in spelling and grammar because it was influenced by the Indonesian language, and lack of grammar knowledge. As noted, for example response by S5, S6, and S7:

"During the writing process, I have problems developing ideas in writing, and difficulty in vocabulary and grammar" (S5).

"My difficulty in writing is the creation of ideas due to a lack of vocabulary and grammar skills "(S6).

"My problem when writing is lack of grammar and vocabulary" (S7).
These were similar to the previous studies in the same topic (Al-hamlan \& Baniabdelrahman, 2015; Boroujeni \& Fard, 2013). Based on the response of the students, it can be summed up that the students' ability in writing was in sufficient level. This might be caused by the low motivation for reading and practicing the textbook and also the difficulties in writing. This result shows that the students are in favor taught different types of text and provide good material to solve their lacks in writing. This support Nation \& Macalister (2010) view regarding this matter. They contend that lacks is an important part of need analysis which involve looking at where leaners at present who proposes that necessities such as learning.

\section{Wants}

Wants are described as "what the leaners think they need" (Nation \& Macalister, 2010). The following table 3 will illustrate the result of need analysis on students' wants.

Table 3. Percentage and frequencies for want in writing skill

\begin{tabular}{lcc}
\hline \multicolumn{4}{c}{ Statement } & Frequencies \\
\hline In your opinion, what aspects of writing you might expect in a writing course? & Yes & No \\
\hline a. Improvement of vocabulary mastery & $23(100 \%)$ & - \\
b. Improvement on cohesion, coherence, and spelling & $20(87 \%)$ & $3(13 \%)$ \\
c. Improvement of grammar & $23(100 \%)$ & - \\
d. Improvement of writing material which stimulates students to write & $22(96 \%)$ & $1(4 \%)$ \\
e. Improvement of knowledge of academic writing & $23(100 \%)$ & - \\
f. Improvement of mastering text types & $23(100 \%)$ & - \\
\hline When you study in writing class, what type of text you might want to write? & & \\
\hline a. Writing literature text such as drama, novel, short story, etc. & $20(87 \%)$ & $3(13 \%)$ \\
b. Writing factual text in daily life & $21(91 \%)$ & $3(13 \%)$ \\
c. Writing imagination text & $16(70 \%)$ & $7(30 \%)$ \\
\hline
\end{tabular}

From table 3, it can be seen that most students preferred material which improves their vocabulary mastery, improvement of grammar, an improvement on knowledge of academic writing, and improvement on mastering text types.

Furthermore, the data of questionnaire was also strengthened by the interview result that the students highly preferred material which improves their knowledge of academic writing, materials of how to develop ideas and the structure of a text such as introduction, body, and conclusion. Then it is also important to study organization, grammar, mechanics, and spelling of text', as represented by S8 and S9:

"I expect to learn grammar since English grammar is different from Indonesian, and then I expect to learn how to develop ideas and organize writing." (S8).
"The things I would like to learn are how to organize text and also grammar" (S9).

In brief, from the result of the questionnaire and interview, it reported that most of the students need to be guided with the material that they most need in writing class.

\section{CONCLUSION}

Needs analysis is an important stage in developing English as a foreign language teaching materials which are appropriate with the leaners characteristics and learners needs. The result of the needs analysis questionnaires and interview shows that students need to learn a number of text types, need to write varies of text, mastering writing skill and writing techniques to complete writing tasks, need to have good proficiency of writing course, good ability of writing varies of text and need to solve the difficulties in their 
writing skills. Furthermore, most of the students prefer on material that meet their interest which improves several aspect of writing, highly preferred writing varies of text, highly preferred writing activities which enable students to have good writing skills, and their vocabulary.

Based on the conclusion, it is highly recommended that there will be a model of teaching material of writing which is appropriate with the students' needs, characteristics, curriculum and purposes of English department students of Muhammadiyah University of Mataram, West Nusa Tenggara Indonesia. Further research regarding the need analysis on learning writing in a wi der context involving more students would be a great help for the improvement of teaching and learning writing in Indonesia EFL context.

\section{REFERENCES}

Al-hamlan, S., \& Baniabdelrahman, A. A. (2015). A needs analysis approach to EFL syllabus development for second grade students in secondary education in Saudi Arabia: A descriptive analytical approach to students' needs. American International Journal of Contemporary Research, 5(1).

Alwasilah, A. C. (2002). Pokoknya kualitatif: Dasardasar merancang dan melakukan penelitian qualitatif. Pustaka Jaya.

Ampa, A. T., \& Quraisy, H. (2018). Needs analysis of the English writing skill as the base to design the learning materials. SHS Web of Conference 42, 00050, 1-6. doi: 10.1051/shsconf/20184200050.

Augusto-Navarro, E. H. (2015). The design of teaching materials as a tool in eflteacher education: Experiences of a Brazilian teacher education program. Ilha Do Desterro, 68(1), 121-137. doi: 10.5007/2175-8026.2015v68n1p121.

Bogdan, R., \& Biklen, S. K. (1998). Qualiative research for education: An introduction to theories and methods. Allyn and Bacon.

Boroujeni, S. A., \& Fard, F. M. (2013). A needs analysis of English for specific purposes (ESP) course for adoption of communicative language teaching: A case of Iranian first-year students of educational administration. International Journal of Humanities and Social Science Invention, 2(6), 2319-7722.

Bouckaert, M. (2018). Current perspectives on teachers as materials developers: Why, what, and how? RELC Journal, 1-18. doi: 10.1177/0033688218810549.

Bouzid, H. A. (2017). An evaluation of selected moroccan ELT textbooks: A standards-based approach perspective. Indonesian Journal of Applied Linguistics, 7(1), 229-238. doi: 10.17509/ijal.v7i1.6879.
Cruz Rondón, E. J., \& Velasco Vera, L. F. (2016). Understanding the role of teaching materials in a beginners' level English as a foreign language course: A case study. Profile, 18(2), 125-137. doi: 10.15446/profile.v18n2.52813.

Darici, A. (2016). The importance of needs analysis in materials development. In M. Azarnoosh, M. Zeraatpishe, A. Faravani, \& H. R. Kargozari (Eds.), Issues in Material Development (pp. 1219). Sense Publisher.

Dörnyei, Z. (2003). Questionnaires in second language. In Mahwah: Lawrence Erlbaum Associates. Lawrence Erlbaum Associates.

Fareed, M., Ashraf, A., \& Bilal, M. (2016). ESL learners' writing skills: Problems, factors and suggestions. Journal of Education \& Social Sciences, 4(2), 83-94. doi: 10.20547/jess0421604201.

Fraenkel, J. R., Wallen, N. E., \& Hyun, H. H. (2012). How to design and evaluate research in education ( $8^{\text {th }}$ ed.). Mcgraw-Hill.

Garton, S., \& Graves, K. (2014). Materials in ELT: current issues. In S. Garton \& K. Graves (Eds.), International perspectives on materials in ELT (pp. 1-285). Palgrave Macmillan. doi: 10.1017/CBO9781107415324.004.

Garton, S., \& Graves, K. (2014). Identifying a research agenda for language teaching materials. The Modern Language Journal, 98(2), 654-657. doi: 10.1111/j.1540-4781.2014.12094.x.

Ghufron, M. A., Saleh, M., Warsono., \& Sofwan, A. (2016). A model of research paper writing instructional materials for academic writing course. English Language Teaching, 9(3), 1. doi: 10.5539/elt.v9n3p1.

Ibrahim, H., Ali, H., Rahman, A., \& Salih, A. (2013). Perceived views of language teachers on the use of needs analysis in ESP materials writing, 6(3), 11-19. doi: 10.5539/elt.v6n3p11.

Işik, A. (2018). ELT materials evaluation: A system and criteria. Theory and Practice in Language Studies, 8(7), 797. doi: 10.17507/tpls.0807.11.

Kashoob, M. M. D. (2018). Evaluating ELT materials with specific reference to colleges of applied sciences general foundation programme in Oman: Towards a viable checklist. doi: 10.1515/iral.1999.37.2.111.

Linh, N. D., \& Suppasetseree, S. (2016). The IAFOR Journal of Language Learning 2(1), 48-66.

Macalister, J. (2016). Adapting and adopting materials. In M. Azarnoosh, M. Zeraatpisha, A. Faravani, \& H. R. Kargozari (Eds.), Issues in material development (pp. 1-219). Sense Publisher.

Mcgrath, I. (2013). Teaching materials and the roles of EFL/ESL teachers, practice and theory. In Bloomsbury. doi: 10.1017/CBO9781107415324.004.

Merriam, S. B. (2012). Qualitative research and case study application in education.

Mishan, F., \& Timmis, I. (2015). Materials 
development for TESOL. doi: 10.1093/elt/ccx062.

Nation, \& Macalister. (2010). Language curriculum design. Routledge.

Nunan, D. (1988). The Leaner-centered curriculum. Cambridge: Cambridge University Press.

Richards, J. C. (2014). The ELT textbook. In S. Garton \& K. Graves (Eds.), International perspectives on materials in ELT (pp. 19-36). Palgrave Macmillan.

Roohani, A., \& Sharifi, M. (2015). Evaluating visual elements in two EFL textbooks. Indonesian Journal of Applied Linguistics, 4(2), 68-77. doi: 10.17509/ijal.v4i2.684.

Rostami, F., \& Zafarghandi, A. M. (2014). EAP needs analysis in Iran: The case of university students in chemistry department. Journal of Language Teaching and Research, 5(4), 924-934. doi: 10.4304/jltr.5.4.924-934.

Shree, J., Mohd, P., Nor, S., \& Din, R. (2014). User needs analysis in learning argumentative writing via mobile platform. Procedia - Social and Behavioral Sciences, 118, 198-205. doi: 10.1016/j.sbspro.2014.02.027.

Silverman, D. (2005). Doing qualitative research. SAGE Publication.

Soleimani, H., \& Esmaili, M. (2016). Technology in materials development: A CALL perspective. In M. Azarnoosh, M. Z. Pishe, A. Faravani, \& H. reza Kargozari (Eds.), Issues in material development (pp. 1-219). Sense Publisher.

Spirovska Tevdovska, E. (2015). Selecting and adapting materials in the context of English for academic purposes- Is one textbook enough? The Journal of Teaching English for Specific and Academic Purposes, 3(1), 115-120.

Sumarsono, D., Bagis, A. K., \& Arrafii, M. A. (2017). Students' need to develop English writing materials. Lingua Cultura, 11(November), 6771. doi: 10.21512/lc.v11i2.1504.

Tjalla, M., Akil, M., \& Hamra, A. (2017). The analysis of EFL students' needs for writing materials development, 6(8), 313-317. doi: 10.21275/ART20175922.

Tomlinson, B. (2012). Materials development for language learning and teaching. In Language Teaching. doi: 10.1017/S0261444811000528.

Tomlinson, B. (2013). Developing Materials for language teaching. In Bloomsbury (second). Bloombury.

Tomlinson, B. (2016). The importance of material development for language learning. In $M$. Azarnoosh, M. Zeraatpishe, A. Faravani, \& H. R. Kargozari (Eds.), Issues in Material Development (pp. 1-219). Sense Publisher. doi: 10.1017/CBO9781107415324.004.

Tomlinson, B., \& Masuhara, H. (2018). The complete guide to the theory and practice of materials development for language learning. Wiley Backwell. doi: 10.2307/2071122.

Widodo, H. P. (2015). The development of vocational English materials from a social semiotic perspective : Participatory action research (Issue March) [University of Adelaide]. Retrieved from:

https://digital.library.adelaide.edu.au/dspace/bitst ream/2440/97910/2/02whole.pdf

Yin, R. K. (1994). Case study research: Design and method. SAGE Publication.

Yundayani, A. (2018). Present situation analysis: Students' early characteristics in writing for academic purposes. English Review: Journal of English Education, 6(2), 119-126. doi: 10.25134/erjee.v6i2.1262.

Yundayani, A., Emzir, \& Rafli, Z. (2017). Need analysis: The writing skill instructional material context for academic purposes. English Review: Journal of English Education, 6(1), 59-70. doi: 10.25134/erjee.v6i1.771.

Zohoorian, Z. (2015). A needs analysis approach: An investigation of needs in an EAP context. Theory and Practice in Language Studies, 5(1), 58. doi: 10.17507/tpls.0501.07. 